(C) 1992 ISIJ

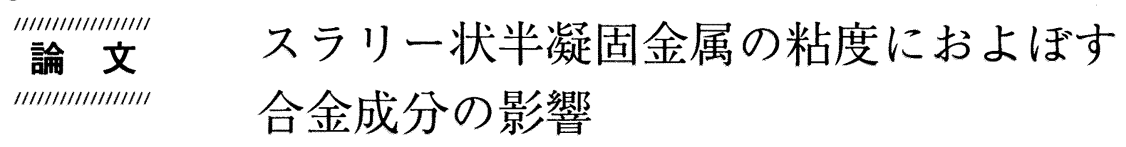

平居 正純* . 竹林 克浩*2.吉川 雄司 $* 3$

\title{
Effect of Chemical Composition on Apparent Viscosity of Semi-solid Metals
}

\author{
Masazumi HiRaI, Katsuhiro TAKEBAYASHI and Yuji YoshIKaWA
}

\section{Synopsis :}

Stirring experiments of $\mathrm{Al}, \mathrm{Cu}$ and $\mathrm{Fe}$ semi-solid alloys on continuous cooling were carried out to investigate the effect of chemical composition and stirring conditions on the apparent viscosity of semi-solid metals.

The apparent viscosity of every alloy increased with increasing solidification rate and decreasing shear rate and the critical fraction solid for fluidity increased with decreasing solidification rate and increasing shear rate. The equation for apparent viscosity $\eta_{a}$ of semi-solid alloy is proposed as follows,

$$
\begin{aligned}
& \eta_{a}=\eta_{L a}\left\{1+\frac{\alpha \rho_{m} C^{1 / 3} \dot{\gamma}^{-4 / 3}}{2\left[1 / f_{S}-1 /\left(0.72-\beta C^{1 / 3} \dot{\gamma}-1 / 3\right)\right]}\right\} \quad(\mathrm{Pa} \cdot \mathrm{s}) \\
& \alpha=2.03 \times 10^{2}(X / 100)^{1 / 3} \\
& \beta=19.0(X / 100)^{1 / 3}
\end{aligned}
$$

where $\eta_{L a}$ is the apparent viscosity of liquid, $\rho_{m}$ is the density of alloy, $C$ is solidification rate, $\dot{\gamma}$ is shear rate and $f_{S}$ is fraction solid. The $\alpha, \beta$ values depended on chemical composition of alloys and became larger with increasing solute content $X$. These results were explained by the shape parameter value of suspended particles and the trapped liquid volume in suspended particles in semi-solid metals.

Key words : viscosity ; semi-solid metal; viscosity equation of semi-solid metal; shear rate ; critical fraction solid for fluidity; solidification rate.

\section{1. 緒 \\ 言}

金属の凝固中に攪拌を与えて固相と液相が混在したス ラリー状の半凝固金属を製造し，その鋳造や加工を行う プロセスにおいて, 半凝固金属の粘度を知ることは重要 である. 半凝固金属の粘度については多くの研究者に よって研究1) 10)16)されており，筆者ら ${ }^{11)} も$ 先に Al-10 $\operatorname{mass} \% \mathrm{Cu}$ 半凝固金属の実験を行い, その粘度におよほ す固相率や懸濁結晶の形態および冷却速度や剪断歪速度 の影響について定量化した．しかし，合金成分の影響に ついては, 定量的に整理されたものはなかった. 本報で は, $\mathrm{Al}-4.5$ mass $\% \mathrm{Cu}, \mathrm{Al}-10$ mass $\% \mathrm{Cu}, \mathrm{Al}-15$ mass $\%$ $\mathrm{Cu}, \mathrm{Al}-3.6$ mass \% Si および $\mathrm{Cu}-8$ mass \% Sn, 2.5 mass \% C 鋳鉄, 0.8 mass \% C 鋼の成分系の半凝固金属製造実験を
行い，半凝固金属の粘度におよぼす成分系の影響につい て検討を行った.

\section{2. 実 験 方 法}

\section{$2 \cdot 1$ 実験装置}

実験装置の概略図を Fig. 1 に示す.Fig. 1 (a) の装 置ではステンレス製のるつぼと黒鉛製パドル型攪拌子を 用い, Fig. 1 (b) の装置では黒鉛るつぼ内にアルミナる つほ（鉄合金実験用）または黒鉛るつほ $(\mathrm{Al}, \mathrm{Cu}$ 合金 実験用）を挿入した高周波溶解炉と，アルミナ系キャス タブル製丸型穓挥子を用いた.

Fig. 1 (a) の装置は主に Al-10 mass\% Cu の実験に用 い, Fig. 1 (b) の装置は実験装置の影響調査のために 行った $\mathrm{Al}-10$ mass\% Cu の実験の他に，他の全ての成分

平成 4 年 2 月 5 日受付 平成 4 年 6 月 5 日受理（Received on Feb. 5, 1992 ; Accepted on June 5, 1992)

* (株)レオテック（Rheo-Technology, 1 Kawasaki-cho Chuo-ku Chiba 260)

*2 (株)レオテック (現: 川崎製鉄(株)) (Rheo-Technology, Now Kawasaki Steel Corp.)

*3 (株)レオテック（現：トピー工業(株))（Rheo-Technology, Now Topy Industries, Ltd.) 
Table 1. Experimental conditions.

\begin{tabular}{|c|c|c|c|c|c|c|c|}
\hline \multirow{2}{*}{ Alloy } & \multirow{2}{*}{$\begin{array}{c}\text { Experiment } \\
\text { numbers }\end{array}$} & \multirow{2}{*}{$\begin{array}{c}\text { Stirrer } \\
\text { size }\end{array}$} & \multirow{2}{*}{$\begin{array}{c}\text { Mean shear } \\
\text { rate/s }\end{array}$} & \multirow{2}{*}{$\begin{array}{l}\text { Mean cooling } \\
\text { rate } / \mathrm{K} \cdot \mathrm{s}^{-1}\end{array}$} & \multirow{2}{*}{$\begin{array}{c}\text { Mean } d f_{s} / d t \\
\text { rate } / s^{-1}\end{array}$} & \multicolumn{2}{|c|}{ Regression results } \\
\hline & & & & & & $a$ value & $f_{\text {scr }}$ value \\
\hline $\begin{array}{l}\mathrm{Al}-10 \% \mathrm{Cu} \\
\mathrm{Al}-10 \% \mathrm{Cu} \\
\mathrm{Al}-10 \% \mathrm{Cu} \\
\mathrm{Al}-4.5 \% \mathrm{Cu} \\
\mathrm{Al}-15 \% \mathrm{Cu} \\
\mathrm{Al}-3.6 \% \mathrm{Si} \\
\mathrm{Cu}-8 \% \mathrm{Sn} \\
\mathrm{Fe}-0.8 \% \mathrm{C} \\
\mathrm{Fe}-2.5 \% \mathrm{C}\end{array}$ & $\begin{array}{r}18 \\
3 \\
5 \\
3 \\
2 \\
2 \\
8 \\
4 \\
4\end{array}$ & $\begin{array}{l}\phi 200 \mathrm{~mm}^{*} \\
\phi 230 \mathrm{~mm} \\
\phi 80 \mathrm{~mm} \\
\phi 80 \mathrm{~mm} \\
\phi 80 \mathrm{~mm} \\
\phi 80 \mathrm{~mm} \\
\phi 100 \mathrm{~mm} \\
\phi 100 \mathrm{~mm} \\
\phi 80 \mathrm{~mm}\end{array}$ & $\begin{array}{r}90 \sim 280 \\
250 \sim 500 \\
25 \sim 200 \\
25 \sim 140 \\
25 \sim 75 \\
25 \sim 75 \\
55 \sim 460 \\
55 \sim 460 \\
50 \sim 125\end{array}$ & $\begin{array}{l}0.05 \sim 0.84 \\
0.06 \sim 0.45 \\
0.03 \sim 0.05 \\
0.02 \sim 0.45 \\
0.04 \\
0.03 \\
0.18 \sim 0.73 \\
0.04 \sim 0.07 \\
0.05 \sim 0.09\end{array}$ & $\begin{array}{c}0.0012 \sim 0.0209 \\
0.0015 \sim 0.0107 \\
0.0007 \sim 0.0013 \\
0.0010 \sim 0.0267 \\
0.0006 \\
0.0007 \\
0.0020 \sim 0.0070 \\
0.0006 \sim 0.0011 \\
0.0003 \sim 0.0006\end{array}$ & $\begin{array}{l}5.89 \sim 92.7 \\
3.38 \sim 22.0 \\
14.1 \sim 144 \\
5.87 \sim 120 \\
96.5 \sim 362 \\
71.0 \sim 80.2 \\
14.2 \sim 632 \\
9.50 \sim 264 \\
55.5 \sim 225\end{array}$ & $\begin{array}{l}0.32 \sim 0.60 \\
0.49 \sim 0.61 \\
0.44 \sim 0.58 \\
0.33 \sim 0.70 \\
0.52 \sim 0.54 \\
0.62 \sim 0.63 \\
0.30 \sim 0.43 \\
0.63 \sim 0.67 \\
0.42 \sim 0.61\end{array}$ \\
\hline
\end{tabular}

* Paddle type

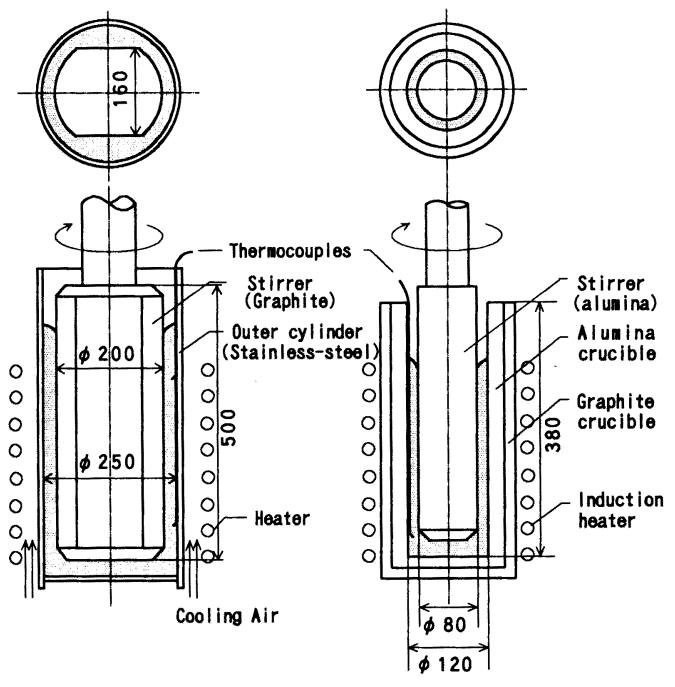

(a) For $\mathrm{Al}-10$ mass $\% \mathrm{Cu}$

(b) For all alloys

Fig. 1. Experimental apparatus.

系の実験に用いた。

実験材料の溶解は Fig. 1 (a) の実験では別の溶解炉 で溶解し, Fig. 1 (b) の実験ではるつぼ内で高周波加熱 によって溶解した。また，実験中の温度測定は, Fig. 1 (a) の装置では高さ方向 2 点, 深さ方向 2 点, Fig. 1 (b) の装置では底から $20 \mathrm{~mm}$ の位置の円周方向に 3 点熱電 対を設置して測定した.

\section{$2 \cdot 2$ 実検条件}

各実験条件および実験材料の組成をそれぞれ Table

1,2 に示す.

これらの装置において攪拌中の粘度は，攪拌子上部に 取り付けたトルクメータによって攪找トルクを測定し, (1)式5によってみかけ粘度として $\eta_{a}$ を求めた.

$\eta_{a}=\frac{\left(r_{2}{ }^{2}-r_{1}{ }^{2}\right) G}{4 \pi r_{1}{ }^{2} r_{2}{ }^{2} \Omega L}$

ここでの実験条件は Reynolds 数が 8500 以上とな

り, Taylor 渦が発生する乱流域 ${ }^{12)}$ と考えられる. なお,

Table 2. Chemical compositions.

\begin{tabular}{l|cccccccc}
\hline \multirow{2}{*}{ Alloy } & \multicolumn{7}{|c}{ Chemical composition/mass\% } \\
\cline { 2 - 8 } & $\mathrm{Al}$ & $\mathrm{Si}$ & $\mathrm{Cu}$ & $\mathrm{Sn}$ & $\mathrm{C}$ & $\mathrm{Mn}$ & $\mathrm{P}$ & $\mathrm{S}$ \\
\hline $\mathrm{Al}-4.5 \% \mathrm{Cu}$ & 94.5 & - & 4.5 & - & - & - & - & - \\
$\mathrm{Al}-10 \% \mathrm{Cu}$ & 90 & - & 10 & - & - & - & - & - \\
$\mathrm{Al}-15 \% \mathrm{Cu}$ & 85 & - & 15 & - & - & - & - & - \\
$\mathrm{Al}-3.6 \% \mathrm{Si}$ & 96 & 3.6 & 0.4 & - & - & - & - & - \\
$\mathrm{Cu}-8 \% \mathrm{Sn}$ & - & - & 92 & 8 & - & - & - & - \\
$\mathrm{Fe}-0.8 \% \mathrm{C}$ & 0.03 & 0.25 & - & - & 0.8 & 0.5 & 0.01 & 0.01 \\
$\mathrm{Fe}-2.5 \% \mathrm{C}$ & 0.03 & 0.25 & - & - & 2.5 & 0.5 & 0.01 & 0.01 \\
\hline
\end{tabular}

剪断歪速度 $\dot{\gamma}$ は平均剪断歪速度として次式によって求 めた.

$$
\dot{\gamma}=2 r_{1} r_{2} \Omega /\left(r_{2}{ }^{2}-r_{1}{ }^{2}\right)
$$

固相率は各成分系の平衡状態図をもとに熱電対による 測温値から換算した. 多元系の 2.5 mass \% C 鋳鉄, 0.8

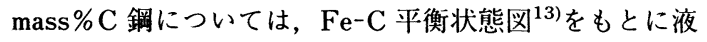
相線および固相線温度補正 ${ }^{14)}$ をた平衡状態図を求め, その状態図をもとに計算した。

\section{3. 実 験 結 果}

\section{$3 \cdot 1$ 各種成分系の半凝固金属の粘度}

$\mathrm{Al}-4.5$ mass $\% \mathrm{Cu}, \mathrm{Al}-10$ mass $\% \mathrm{Cu}, \mathrm{Al}-15$ mass $\% \mathrm{Cu}$, $\mathrm{Al}-3.6$ mass \% Si, 2.5 mass \% C 鋳鉄, $\mathrm{Cu}-8$ mass $\% \mathrm{Sn}$ の各合金についてみかけ粘度と固相率との関係を測定し た結果の例を Fig. 2 に示す.

なお，固相率が高くなり粘度が上昇すると攪䢁子がス リップし, 流動が不均一となる現象が発生したが, 粘度 の解析に当たってはこの部分は除外し, また, トルク值 には機械損值が含まれるためこれを差し引いて補正し た。

いずれの成分系においても, ある固相率でみかけ粘度 は急激に増加した。 また, 冷却速度が大きいほど, 攪拌 速度が小さいほど低固相率から粘度が上昇する傾向が あった。

\section{$3 \cdot 2$ 半凝固金属の粘度におよぼす冷却速度, 禩拌速度 の影整}

各成分系の実験で得られた凝固過程におけるみかけ粘 


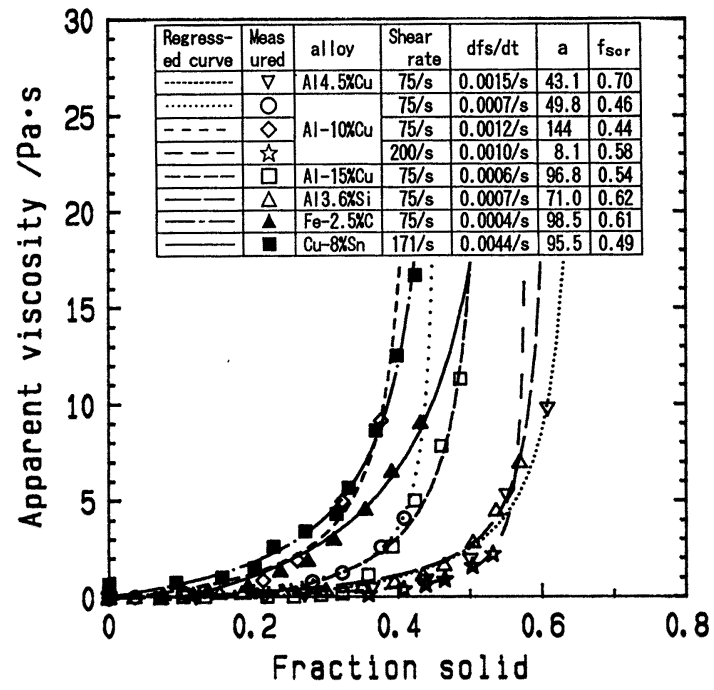

Fig. 2. Relationship between fraction solid and apparent viscosity. The lines are regressed results.

度と固相率の関係について, 前報の $\mathrm{Al}-10$ mass $\% \mathrm{Cu}$ 合 金の実験結果と同様に懸濁した固相の形状の影響を考慮 し, 森, 乙竹の理論粘度式年)を基本とした ( 3 )式で半 凝固金属の製造条件および合金成分との関係を解析し た.

$$
\eta_{a}=\eta_{L a}\left|1+\frac{d \cdot S_{r}}{2\left(\frac{1}{f_{s}}-\frac{1}{f_{s c r}}\right)}\right|
$$

ただし，実際の半凝固金属においては，（3)式の $d \cdot S_{r}$ の值は凝固過程における経時変化とともに, チク ソトロピー (Thixotoropy) 性流体として挸拌によって 粘度が変化する現象も含まれるので，ここでは $(4)$ 式に 示すように形状パラメーター $a\left(d \cdot S_{r}\right.$ に比例する物性 值）として解析を行った。

$$
\eta_{a}=\eta_{L a}\left|1+\frac{a}{2\left(\frac{1}{f_{s}}-\frac{1}{f_{s c r}}\right)}\right|(\mathrm{Pa} \cdot \mathrm{s}) \cdots(4)
$$

また, $\eta_{L a}$ 值は本装置の精度では実測が困難なため次 の計算值を用いた．㨽拌によって発生する Taylor 渦を 考慮したトルクを求める式がいくつか提案されている中 で, 高レイノルズ数の場合によく一致すると考えられる Wendt $の$ 式 ${ }^{18)}$ からみかけ液相粘度 $\eta_{L a}$ として求めた。 ここで, 残溶湯の真粘度 $\eta_{L}$ は溶融金属の粘度推定式 ${ }^{19}$ から求めた計算值を使用した.

連続的に得られたトルクデー夕に対し，(4)式をもと に最小二乗法による非線形回帰により形状パラメーター

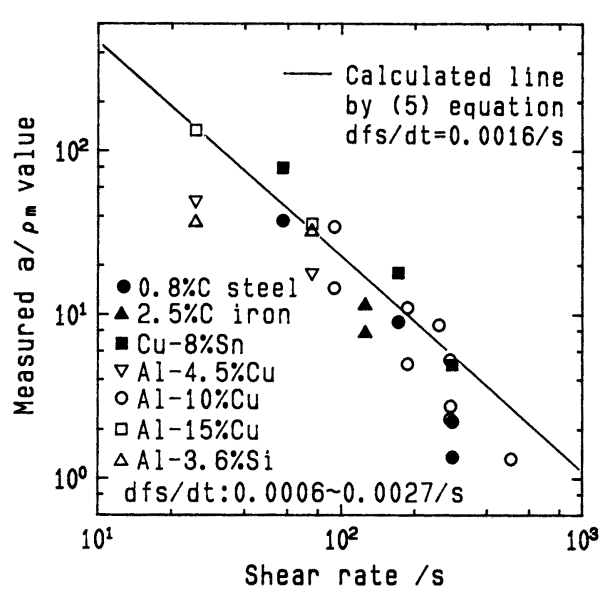

Fig. 3. Effect of shear rate on $a / \rho_{m}$ value.

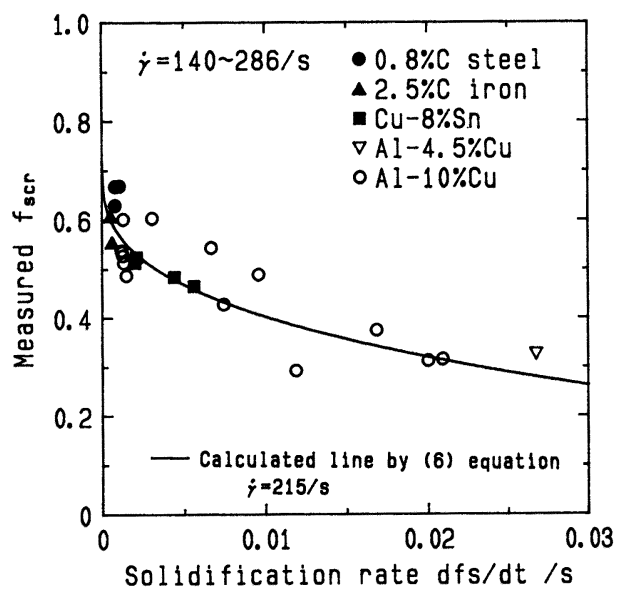

Fig. 4. Effect of solidification rate on critical fraction solid.

$a$ および流動限界固相率 $f_{s c r}$ の值を求めた. $\mathrm{Al}-4.5$ mass $\% \mathrm{Cu}, \mathrm{Al}-10$ mass $\% \mathrm{Cu}, \mathrm{Al}-15$ mass $\% \mathrm{Cu}, \mathrm{Al}-3.6$ mass $\% \mathrm{Si}, 2.5$ mass \% C 鋳鉄および $\mathrm{Cu}-8$ mass $\% \mathrm{Sn}$ の 回㷌結果の例を先の Fig. 2 に示す. 各種成分系半凝固 金属の粘度挙動も ( 4 )式で精度よく整理でき， $a$ 值およ び $f_{s c r}$ 值はいずれも凝固速度 $d f_{s} / d t$ と剪断歪速度との 間に強い相関が見られた．ただし，同じ凝固速度および 剪断歪速度でも $a$ および $f_{s c r}$ 值は成分系によって異な る傾向が見られた．各実験で得られた $a$ および $f_{\text {scr }}$ の 值の範囲を先の実験条件を示した Table 1 にまとめて 示す。また各種成分系について得られた $a$ および $f_{\text {scr }}$ の值と凝固速度および剪断歪速度との関係についての例 を Fig. 3, 4 に示す. 各合金とも凝固速度が大きいほと, 
また剪断歪速度が小さいほど結晶形状パラメーター $a$ 值は大きく, 流動限界固相率 $f_{s c r}$ は小さくなる傾向がみ られたが，その程度は成分系によって若干差があった。

Table 3. $\alpha$ and $\beta$ values in equation (5), (6).

\begin{tabular}{l|c|c|c|c}
\hline \multicolumn{1}{c|}{ Alloy } & $\alpha$ & $\beta$ & $\begin{array}{c}\text { alloy } \\
\text { content } \\
\text { mass } \%\end{array}$ & $\begin{array}{c}\rho_{\boldsymbol{m}} \\
/ \mathrm{Kg} \cdot \mathrm{m}^{-3}\end{array}$ \\
\hline $\mathrm{Al}-4.5 \% \mathrm{Cu}$ & 72.2 & 6.76 & 4.5 & 2460 \\
$\mathrm{Al}-10 \% \mathrm{Cu}$ & 94.2 & 8.82 & 10.0 & 2560 \\
$\mathrm{Al}-15 \% \mathrm{Cu}$ & 108 & 10.1 & 15.0 & 2680 \\
$\mathrm{Al}-3.6 \% \mathrm{Si}$ & 67.0 & 6.27 & 3.6 & 2140 \\
$\mathrm{Cu}-8 \% \mathrm{Sn}$ & 87.5 & 8.19 & 8.0 & 7960 \\
$\mathrm{Fe}-0.8 \% \mathrm{C}$ & 40.6 & 3.80 & 0.8 & 7000 \\
$\mathrm{Fe}-2.5 \% \mathrm{C}$ & 59.4 & 5.56 & 2.5 & 7000 \\
\hline
\end{tabular}

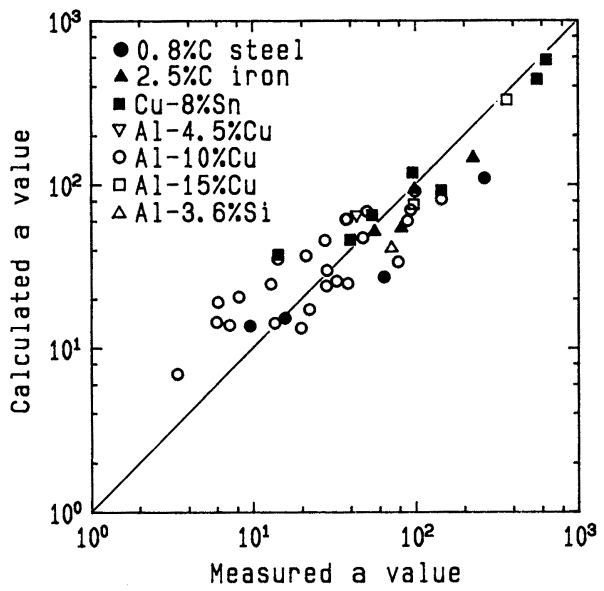

Fig. 5. Comparison of calculated and measured a values.

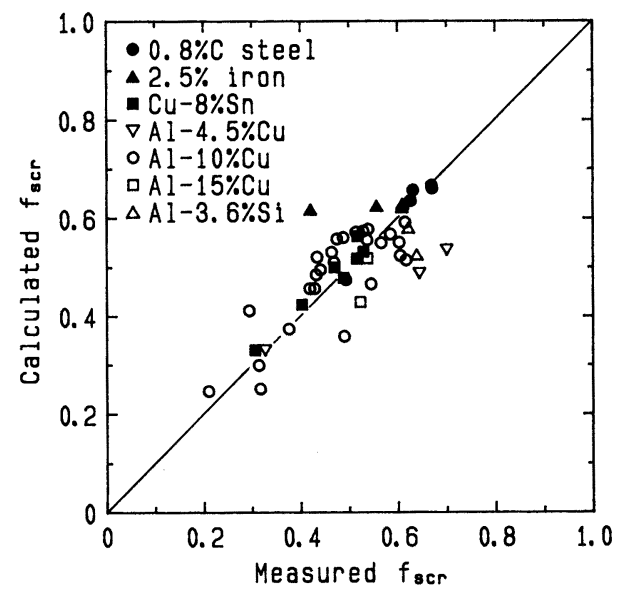

Fig. 6. Comparison of calculated and measured values of critical fraction solid $f_{\text {scr }}$. $a$ 值および $f_{s c r}$ 值は先に得られた $\mathrm{Al}-10$ mass $\% \mathrm{Cu}^{11)}$ 合金の関係式を基本とした 5 ), ( 6 )式の関係が得られ, ( 5 )および $(6)$ 式の係数 $\alpha, \beta$ の値を合金の種類によっ て変えるだけで測定值と計算值がよく一致することがわ かった。ここで得られた各合金での $\alpha, \beta$ はまとめて Table 3 に示す.

$$
\begin{aligned}
& a=\alpha \rho_{m} C^{1 / 3} \dot{\gamma}^{-4 / 3} \quad \text { (形状パラメーター) } \cdots \cdots(5) \\
& f_{s c r}=0.72-\beta C^{1 / 3} \dot{\gamma}^{-1 / 3} \quad \text { (流動限界固相率) } \\
& \text { ここで, } C>0, \quad \dot{\gamma}>0, f_{s c r}>f_{s} \geqq 0 \text { である. }
\end{aligned}
$$

$a$ 值および $f_{s c r}$ 值について( 5$)$ ，（6)式の $\alpha, \beta$ をそ れぞれ Table 3 の值から求めた計算值と測定值を比較 し Fig. 5，6 に示す.また，各種成分系における固相率 と粘度の関係について，(4)，（5)，（6)式によるみか け粘度の計算値と実測値の比較例を Fig. 7 に示すが, 両者はほぼ一致した。ただし，形状パラメーター $a$ は その合金の密度を掛けた値となった。

上記の結果から $\mathrm{Al}$ 合金, $\mathrm{Cu}$ 合金, 鉄鋼も含めた各 種成分系の半凝固金属のみかけ粘度と凝固速度, 剪断歪 速度の製造条件との関係は (4)，（5)，（6)式により統 一的に整理できることがわかった.

\section{$3 \cdot 3$ 半凝固金属のみかけ粘度におよぼす実検装置の影}

半凝固金属の粘度値におよぼす実験装置の違いの影 響について調査するため，実験装置規模および攪拌子 形状の異なる Fig. 1 (a) と Fig. 1 (b) の装置を用いて

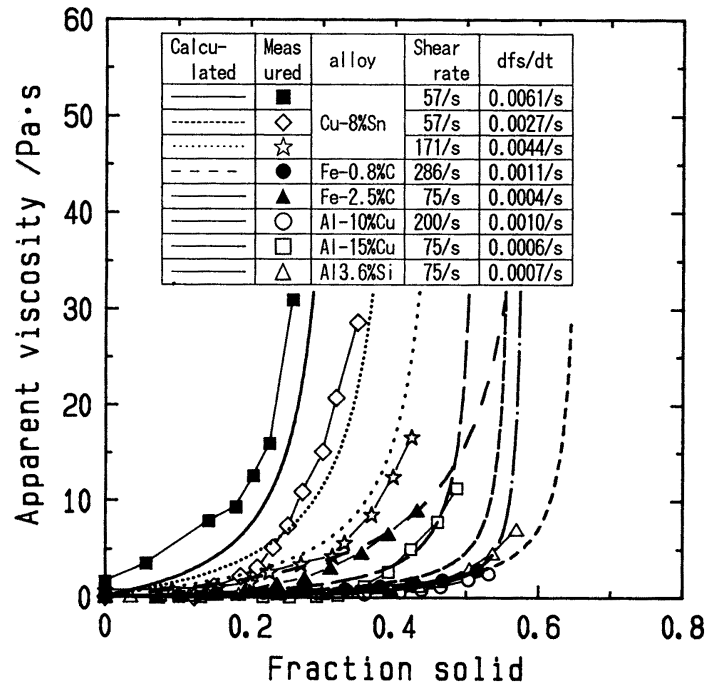

Fig. 7. Comparison of measured and calculated viscosities. 


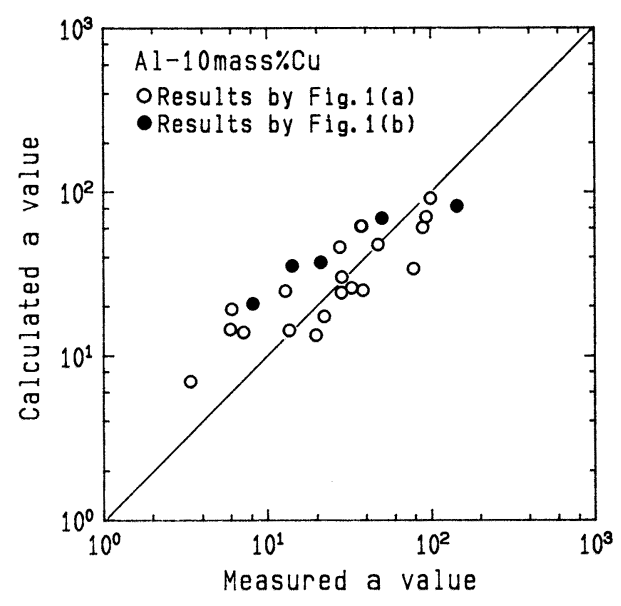

Fig. 8. Effect of experimental apparatus on a value.

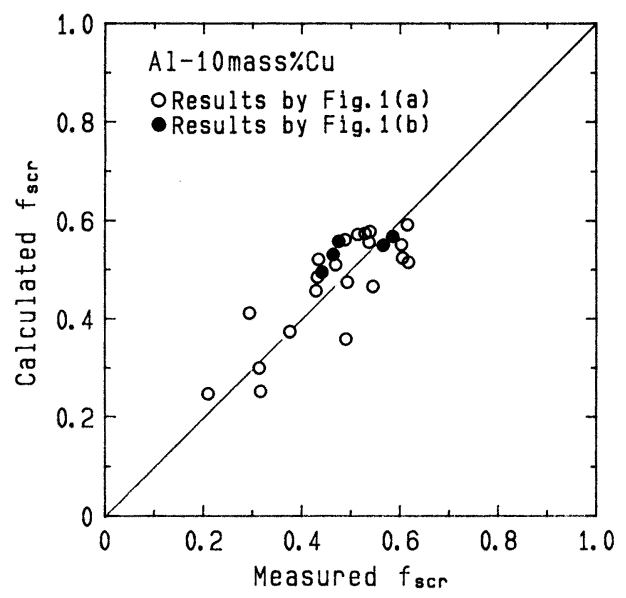

Fig. 9. Effect of experimental apparatus on critical fraction solid.

$\mathrm{Al}-10$ mass \% Cu 合金の攪拌凝固実験を行った。その実 験結果から( 4 )式の粘度式による回帰結果から得られた 各実験の $a$ および流動限界固相率 $f_{s c r}$ の值を Table 1 に示し，粘度式(4)，（5 )，（6 )に，Al-10 mass\% Cu の同じ $\alpha, \beta$ 值を使用した計算值と測定値の関係を Fig. 8,9 に示す。両実験装置の測定值はともに計算值とよ く一致しており, 実験装置間の差の影響はほとんどな かった.

\section{4. 考察}

\section{$4 \cdot 1$ 半凝固金属みかけ粘度式の係数の意味}

前述したように，実験データの解析結果から，各合金
の半凝固金属のみかけ粘度の推定式として (4), (5), ( 6 )式の関係が得られ, 形状パラメーター $a$ の係数 $\alpha$ および流動限界固相率 $f_{s c r}$ の係数 $\beta$ 值は合金によって 異なる結果となった。 $\alpha$ および $\beta$ 值は Table 3 に示し たが，それぞれ次式のような合金成分の溶質濃度の関数 式

$$
\begin{aligned}
& \alpha=2.03 \times 10^{2}(X / 100)^{1 / 3} . \\
& \beta=19.0(X / 100)^{1 / 3} \ldots \ldots \ldots . . .
\end{aligned}
$$

でほほ整理できた。

半凝固金属の攪拌冷却途中における急冷試料の結晶組 織写真の例を Photo. 1，2 に示すが，懸濁結晶の形状 $\left(d \cdot S_{r}\right)$ は製造条件とともに合金によって差があった.

溶質濃度が高い合金ほど, 枝葉の多いばら花状結晶に なりやすく，凸凹の大きい比較的表面積の大きな結晶と なったため, 結晶形状パラメーター $a$ が大きくなると ともに, 結晶内に捕捉される液相量が多くなって流動限 界固相率 $f_{s c r}$ が小さくなり, みかけ粘度が高くなったも のと考えられる.

すなわち, 形状パラメーター $a$ の関数の係数 $\alpha$ や流 動限界固相率 $f_{s c r}$ の係数 $\beta$ の值が合金組成によっ て違った理由として, 結晶の凝固成長や肥大化成長 （Ostwald ripening）が冷却速度とともに合金組成によっ て決まる( 9 )式で示す結晶肥大化速度パラメーター $W$ 值に比例するとされており ${ }^{17) 20)}$ ，特に溶質濃度によっ て結晶形状や形態に差があったためと考えられる.

$$
W=A C_{L}^{-1 / 3}, A=\left[\sigma D T / H\left(1-k_{0}\right) m\right]^{1 / 3} \cdots(9)
$$

これは半凝固金属の凝固速度や剪断歪速度などの製造条 件の違いによって懸濁結晶の形態が変わり, みかけ粘度 に大きく影響した ${ }^{11}$ 現象と同じと考えられる.

高合金や高冷却速度ほど結晶粒径は小さくなり ${ }^{20)}$, 比表面積の大きいばら花状結晶やネットワークを組んた 大きな合体粒となりやすく，また剪断歪速度の増加が ネットワークの分断や結晶粒状化に効果があったものと 考えられる.ただし，先の $(9)$ 式の $A$ 值は溶質元素の 種類によって異なる值であり，（７)，（8)式の係数は厳 密には溶質の種類によって異なり，この分は実験誤差お よび推定誤差となっていると考えられる.

また（ 5 )式の $a$ は合金の密度を掛けた関係式で整 理できたが, これは非ニュートン流体の乱流域のスラ リー状半凝固金属の粘度に対する密度差による慣性力の 影響，または Wendt の式 ${ }^{18)}$ から求めた乱流域の $\eta_{L a}$ 值 の推定精度などが原因と考えられる。

一方, 流動限界固相率 $f_{\text {scr }}$ の最大値が 0.72 となった が, 懸濁固相の形状が等径球の場合の最疎充填状態 (cubic packing) となる固相率は $0.52^{15)}$, 無規則充媜状 


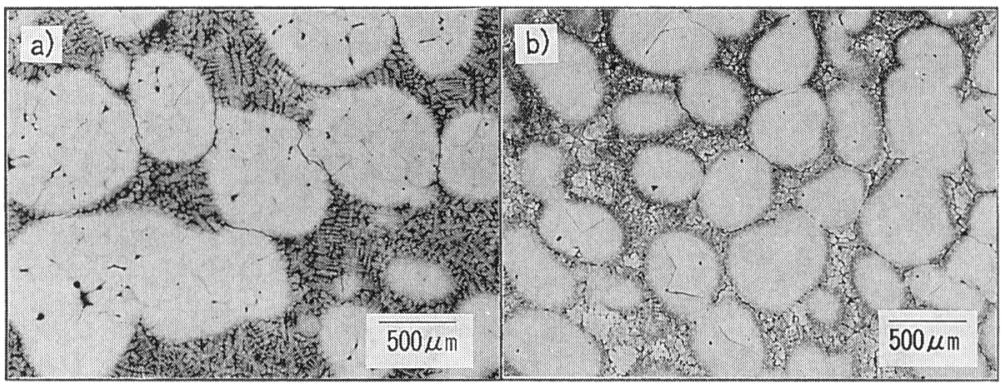

a) Shear rate $=171 / \mathrm{s}, d f_{s} / d t=0.0008 / \mathrm{s}$ b) Shear rate $=457 / \mathrm{s}, d f_{s} / d t=0.0008 / \mathrm{s}$

Photo. 1. Microstructures of water quenched semi-solid 0.8 mass $\% \mathrm{C}^{-}$steel $\left(f_{s}=0.4\right)$.

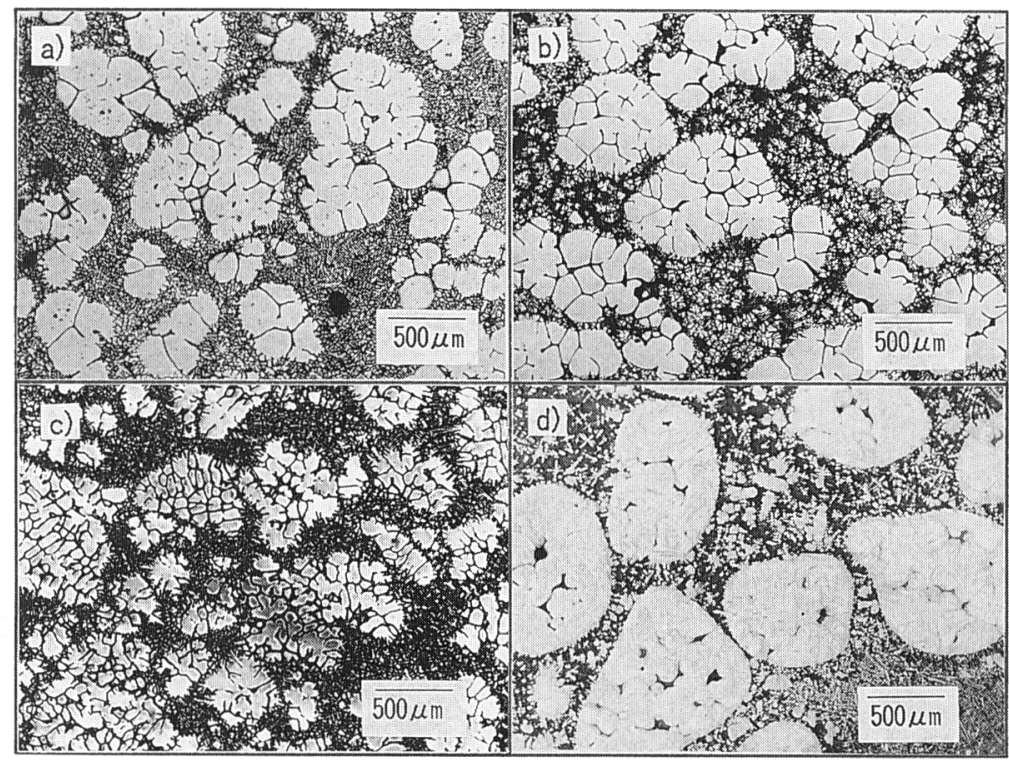
a) $\mathrm{Al}-4.5$ mass $\% \mathrm{Cu}$
Shear rate $=75 / \mathrm{s}, d f_{\mathrm{s}} / d t=0.0015 / \mathrm{s}$
b) $\mathrm{Al}-10$ mass $\% \mathrm{Cu}$
Shear rate $=75 / \mathrm{s}, d f_{\mathrm{s}} / d t=0.0007 / \mathrm{s}$
c) $\mathrm{Cu}-8$ mass $\% \mathrm{Sn}$
Shear rate $=57 / \mathrm{s}, d f_{s} / d t=0.0027 / \mathrm{s}$
d) 2.5 mass $\%$ C-iron
Shear rate $=57 / \mathrm{s}, d f_{s} / d t=0.0004 / \mathrm{s}$

Photo. 2. Microstructures of water quenched semi-solid alloys $\left(f_{s}=0.2 \sim 0.4\right)$.

態 (random close packing) で $0.64^{8)}$, 最密充壃状態 (hexagonal close packing) で $0.74^{8)}, 2$ 種球径の混合物 の場合の最大充填固相率で $0.85^{23)}$ となることから考え て妥当な值と考えられる.

\section{$4 \cdot 2$ 各種成分系における粘度式による計算値と文献値 の比較}

半凝固金属のみかけ粘度に関する文献データの中で, Joly ら $^{2)}$ および Nan $ら^{7)}$ の Sn-15 mass\% Pb 合金の例 について，（4)，（5），（6）の粘度式による計算值と比 較し Fig. 10, 11 に示す。半凝固金属の粘度挙動と冷却 速度および剪断歪速度との関係は実験条件の差および初
晶の沈降や浮上の影響が入りやすいなど粘度測定の困難 さを考慮すれば傾向はよく一致しているといえる.

これらの結果から, 実験データのない成分系のみかけ 粘度も(4)，（5)，（6）の粘度式によって概略推定でき るものと考えられる．ただし，共晶合金の場合は凝固形 態が通常の成分系に比べ差が大きく, 攪拌凝固した半凝 固金属の懸濁結晶は比較的細かな粒状晶となり粘度挙動 も異なると考えられるため, 流動限界固相率以下の固相 率の残溶融金属の組成が共晶組成になる合金は適用でき ないと考えられる. 


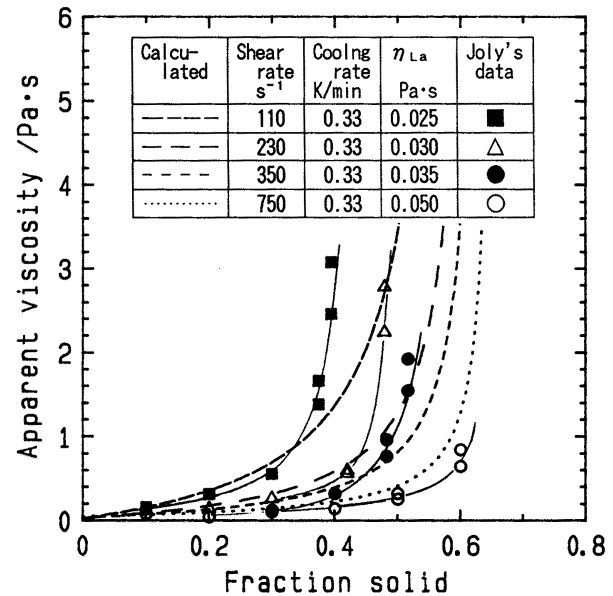

Fig. 10. Calculated results of apparent viscosity of $\mathrm{Sn}-15$ mass $\% \mathrm{~Pb}$ alloy. The data of solid symbols are the results of Joly's in Ref. (2).

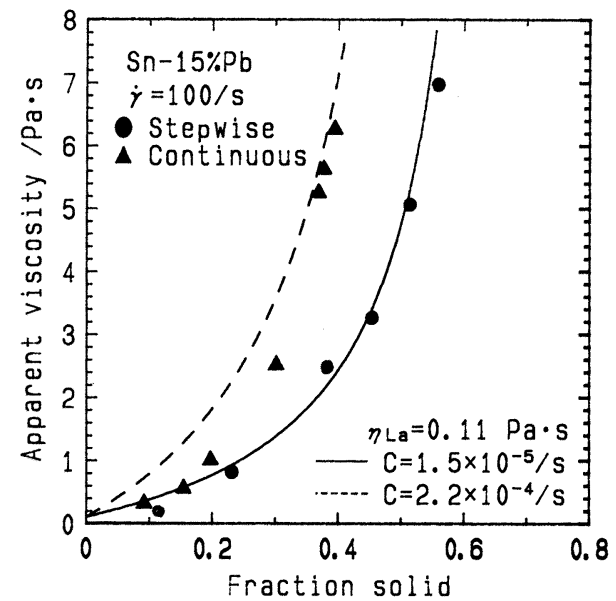

Fig. 11. Calculated results of apparent viscosity of $\mathrm{Sn}-15$ mass $\% \mathrm{~Pb}$ alloy. The data of solid symbols are the results of Nan's in the stepwise (O) and continuous $(\triangle)$ cooling in Ref. $(7)$.

\section{$4 \cdot 3$ 粘度におよぼす冷却パターンの影響}

半凝固後に等温保持をした場合または階段的冷却をし た場合の半凝固金属の粘度は連続的に冷却した場合と比 較して差があるため, 前者を定常状態の粘度として区別 している文献が多い.しかし, 等温保持や階段的冷却の 場合は半凝固状態の時間が長くなるため, その間での懸 濁結晶の粗大化や球状化が促進され, 結晶形状や形態が 変化する ${ }^{21)}$ ため, 粘度もそれに伴って当然変化すると

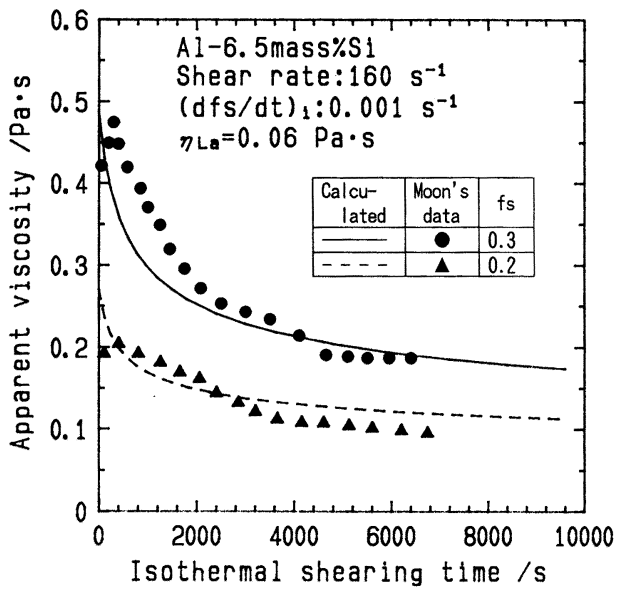

Fig. 12. Change in apparent viscosity of $\mathrm{Al}-6.5$ mass\% $\mathrm{Si}$ alloy during isothermal shearing. The data of solid symbols are the results of Moon's in Ref. (22). The $\left(d f_{s} / d t\right)_{i}$ is initial solidification rate.

考えられる（4)，（5)，（6 )式は連続冷却法によって 求めた粘度式であり，凝固速度は固相率が $0 \sim 0.4$ の平 均凝固速度から求めたが，等温保持や階段的冷却の場合 は凝固時間に等温保持時間も加えた平均凝固速度で粘度 計算すればよいと考えられる．先の Fig. 11 に示した Nan $ら^{7)}$ の階段的冷却法と連続的冷却法の粘度の比較に おいて, 上述の方法で求めた平均凝固速度の差で説明で きた.また，Fig. 12 に示すように Al-6.5 mass\% Si 合 金の等温保持実験 ${ }^{22)} に お け る$ 半凝固金属の粘度の低下 挙動も，この考え方の計算值とよく一致した.

すなわち，等温保持によって結晶の形状が粗大化，お よび粒状化が促進されるが，連続冷却の場合も冷却速度 が遅い場合には等温保持と同様に結晶の粗大化と粒状 化が促進される.すなわち，結晶の形状は主に結晶の Ostwald ripening 現象 ${ }^{21)}$ にって左右されるものと考え られ，半凝固金属の粘度は連続冷却や階段的冷却または 等温保持の場合でも，その状態に到るまでの全時間を含 めた平均凝固速度 (Ripeningに対する時間指標)によっ て主に左右されるものと考えられる.

ただし，Fig. 12 の結果から見られるように，等温保 持時間と粘度の関係の低下程度は計算推定值の方が文献 の測定值に比べてやゃ小さくなっているが，これは測定 值には保持によるチクソトロピー性の影響もあるためと 考えられる。

なお，（5)，（6 式の凝固速度は固相率の 0 0.4の 間の平均凝固速度としたが，実際には固相率 0 からそ 
れぞれの粘度測定時までの平均凝固速度とした方が推定 精度は高くなるものと考えられる.

\section{5. 結}

\section{言}

7 種類の合金の穓拌凝固実験を行い半凝固金属の粘度 におよぼす合金成分の影響を調査し,以下の結果を得た.

(1)各合金とも, 固相率とみかけ粘度の関係は凝固速 度と剪断歪速度に影響され, 凝固速度が小さいほど, ま た剪断歪速度が大きいほどみかけ粘度が低く流動限界固 相率は大きくなる傾向があった。

( 2 )半凝固金属の粘度は懸濁結晶のパラメーターと流 動限界固相率の関数で整理でき, みかけ粘度と凝固速度 および剪断歪速度の関係は, 各合金とも先に得られた $\mathrm{Al}-10$ mass \% Cu 合金の粘度式 ${ }^{11)} の$ 係数の值を変えるた けで統一的に整理できた．各係数の值は合金の密度と溶 質量の関数式となった.

$$
\eta_{a}=\eta_{L a}\left|1+\frac{\alpha \rho_{m} C^{1 / 3} \dot{\gamma}^{-4 / 3}}{2\left(\frac{1}{f_{s}}-\frac{1}{0.72-\beta C^{1 / 3} \dot{\gamma}^{-1 / 3}}\right)}\right|
$$

$(\mathrm{Pa} \cdot \mathrm{s})$

$$
\begin{aligned}
& \alpha=2.03 \times 10^{2}(X / 100)^{1 / 3} \\
& \beta=19.0(X / 100)^{1 / 3}
\end{aligned}
$$

が得られた。

( 3 ) 合金成分の濃度が大きいほど, $\alpha, \beta$ の值が大き く粘度が高くなる傾向がみられた。これは合金濃度が大 きいほど懸濁結晶の形状パラメーター值および結晶内に トラップされた液相量が大きくなるためと考えられる.

最後に，本研究にあたって，ご助言をいただいた(株) レオテックの郡司好喜顧問に深く感謝いたします。

\section{記 号}

$C:$ 固相率 0 0.4 までの凝固速度 $d f_{s} / d t\left(\mathrm{~s}^{-1}\right)$

$C_{L}:$ 液相溶質濃度 $(\operatorname{mass} \%)$

$D:$ 溶質の拡散係数 $\left(\mathrm{m}^{2} \cdot \mathrm{s}^{-1}\right)$

$G:$ 攪拌トルク $(\mathrm{N} \cdot \mathrm{m})$

$H:$ 溶解のエンタルピー $\left(\mathrm{J} \cdot \mathrm{m}^{-3}\right)$

$L$ : 撹找子浸漬長さ (幾何学的に求めた值) $(\mathbf{m})$

$S_{r}$ : 眯濁結晶の比表面積 (表面積 $/$ 体積) $\left(\mathrm{m}^{-1}\right)$

$T:$ 液相温度 $(\mathrm{K})$

$W:$ 結晶肥大化速度パラメーター

$X:$ 合金中の主溶質濃度 (mass\%)

$a:$ 懸濁結晶の形状パラメーター

\section{$d:$ 懸濁粒子の平均径 $(\mathrm{m})$}

$f_{s}$ : 固相率

$f_{\text {scr }}:$ 流動限界固相率

$k_{0}:$ 平衡分配係数

$m:$ 液相線勾配 $\left(\mathrm{K} \cdot \operatorname{mass} \%{ }^{-1}\right)$

$r_{1}$ : 攪拌子半径 (パドル型攪找子の場合は長軸値) $(\mathrm{m})$

$r_{2}:$ 䚌找槽半径 $(\mathrm{m})$

$\dot{\gamma}:$ 剪断歪速度 $\left(\mathrm{s}^{-1}\right)$

$\eta_{a}$ : 半凝固金属のみかけ粘度 $(\mathrm{Pa} \cdot \mathrm{s})$

$\eta_{L a}:$ 液相みかけ粘度 $(\mathrm{Pa} \cdot \mathrm{s})$

$\rho:$ 残溶融金属と同じ組成の凝固密度 $\left(\mathrm{kg} \cdot \mathrm{m}^{-3}\right)$

$\rho_{m}:$ 合金の液相線温度での密度 $\left(\mathrm{kg} \cdot \mathrm{m}^{-3}\right)$

$\sigma:$ 固液の界面張力 $\left(\mathrm{J} \cdot \mathrm{m}^{-2}\right)$

$\Omega:$ 攪拌角速度 $\left(\mathrm{rad} \cdot \mathrm{s}^{-1}\right)$

\section{文献}

1 ) D. B. Spencer, R. Mehrabian and M. C. Flemings: Metall. Trans., 3 (1972), p. 1925

2 ) P. A. Joly and R. Mehrabian: J. Mater. Sci., 11 (1976), p. 1393

3 ) 市川理衛, 三輪謙治: 日本金属学会誌, 42 (1978), p. 1023

4 ）森 信孝, 大城桂作, 松田公扶: 日本金属学会誌, 48 (1984), p. 936

5 ) 渋谷明彦, 有原和彦, 中村 泰: 鉄と鋼, 66 (1980), p. 1550

6 ) V. Laxmanan and M. C. Flemings: Metall. Trans. A, 11 (1980), p. 1927

7 ) W. Nan, S. Guangji and Y. Hanguo: Materials Trans. JIM, $31(1990) 8$, p. 715

8 ) L. Turng: Rheological modelling and numerical simulation of semi-solid $\mathrm{Sn}-15 \% \mathrm{~Pb}$ alloy for netshape die-casting process, Cornell University (1990)

9 ) T. Z. Kattamis and T. J. Piccone: Material Sci. Eng., A, 131 (1991), p. 265

10) S. B. Brown and P. Kumar: Int. Conf. on Semi-Solid Process., Sophia-antipolis, France (1990)4

11) 平居正純, 竹林克浩, 吉川雄司, 山口隆二: 鉄と鋼,78 (1992), p. 902

12）機械工学便覧 (新版)（日本機械学会編）（1987）, p. A5-128

13）田中良平: 鉄と鋼, 53 (1967), p. 1586

14）平居正純, 金丸和男, 森 久: 学振 19 委, 凝固現象協議 会資料, 凝固 46 (1968)

15) 森 芳郎, 乙竹 直: 化学工学, 20 (1956), p. 488

16) K. Ichikawa, S. Ishizuka and Y. Kinoshita: Trans. Jpn. Inst. Met., 29 (1988), p. 598

17）岡本 平: 日本金属学会会報, 17 (1978),p. 731

18) F. Wendt: Ingen. Arch., 4 (1933), p. 577

19）平居正純: 鉄と鋼, 78 (1992), p. 399

20) T. Z. Kattamis, M. C. Flemings: Trans. Metal. Soc. AIME, 239 (1967), p. 1504

21) 野田真人, 古川雅三, 木島三樹男, 岩田至弘: 材料とプロセ ス, 4 (1991), p. 688

22) H.-K. Moon: Ph. D. Thesis, Massachusetts Institute of Technology, Cambridge, MA (1990)

23) R. K. McGeary: J. Amer. Ceram. Soc., 20 (1937), p. 155 